\title{
Pendekatan Scientific Approach dalam Mengembangkan Alat Praktikum IPA Terintegrasi Lingkungan untuk Meningkatkan Keterampilan dan Kreativitas Guru IPA
}

\author{
${ }^{1}$ Khaerus Syahidi, ${ }^{2}$ Laxmi Zahara, ${ }^{3}$ Nunung Ariandani \\ ${ }^{1,2}$ Prodi Pendidikan Fisika, FMIPA, Universitas Hamzanwadi, Jln. TGKH. M. Zainuddin \\ Abdul Madjid No. 132 Pancor Selong, Lombok Timur, NTB, 83611 \\ ${ }^{3}$ Prodi Pendidikan Biologi, FMIPA, Universitas Hamzanwadi, Jln. TGKH. M. Zainuddin \\ Abdul Madjid No. 132 Pancor Selong, Lombok Timur, NTB, 83611 \\ Email Korespondensi: khaerussyahidi@gmail.com , laxmizahara3@gmail.com, \\ nunungariandani@gmail.com
}

\begin{tabular}{|c|c|}
\hline Article Info & Abstract \\
\hline $\begin{array}{l}\text { Article History } \\
\text { Received: November } \\
\text { Revised: December } \\
\text { Published: December }\end{array}$ & \multirow[b]{2}{*}{$\begin{array}{l}\text { Scientific Approach Approach in Developing Environmentally Integrated } \\
\text { Science Practicum Tools to Enhance Science Teacher's Skills and Creativity. } \\
\text { This PkM program aims to improve: (1) teacher skills in designing and } \\
\text { developing KIT of Natural Sciences practicum tools, Practical tools, } \\
\text { laboratory management SOP as well as integrated science materials with the } \\
\text { potential of the surrounding environment. The method used in achieving these } \\
\text { objectives is the implementation of inservice in the form of training and } \\
\text { assistance. The training carried out is a training to develop the skills and } \\
\text { creativity of science teachers in the production / design of an integrated } \\
\text { natural science practicum device based on the environment and training to } \\
\text { design learning using a scientific approach that utilizes the KIT of science that } \\
\text { has been produced. Assistance is also carried out related to improving the } \\
\text { ability of teachers to explore, elaborate and reflect on integrated science } \\
\text { teaching materials. The output of this activity is in the form of KIT of } \\
\text { integrated environment-based practicum tools equipped with SOP for the } \\
\text { management of practicum with environmental conditions; Integrated practicum } \\
\text { tools in integrated science learning (RPP, LKS, teacher's guide) to support } \\
\text { scientific approach learning; Integrated science laboratory management SOP; } \\
\text { Refresher teaching materials integrated science materials; Scientific article } \\
\text { (national publication). The results of the activities that have been achieved } \\
\text { include, increased understanding and skills of natural science teachers in the } \\
\text { Jerowaru SMPN I Natural Science teacher group on integrated science } \\
\text { material, increasing teachers understanding of learning with an inquiry } \\
\text { approach, increasing the skills of science teachers designing / making KIT } \\
\text { Simple science made from raw materials from the surrounding environment to } \\
\text { support science learning using the inquiry discovery approach (scientific } \\
\text { approach), increasing the ability of science teachers to design learning tools } \\
\text { with the inquiry inquiry approach (scientific approach), training the skills and } \\
\text { abilities of science teachers in partner schools in implementing science } \\
\text { learning with inquiry discovery (scientific approach) approach. }\end{array}$} \\
\hline $\begin{array}{l}\text { Keywords } \\
\text { Skills, integrated IPA } \\
\text { practicum KIT, scientific } \\
\text { approach }\end{array}$ & \\
\hline Informasi Artikel & Abstrak \\
\hline $\begin{array}{l}\text { Sejarah Artikel } \\
\text { Diterima: November } \\
\text { Direvisi: November } \\
\text { Dipublikasi: November }\end{array}$ & $\begin{array}{l}\text { Program PkM ini bertujuan untuk meningkatkan: (1) keterampilan guru } \\
\text { merancang dan mengembangkan KIT alat praktikum IPA, Perangkat } \\
\text { praktikum, SOP tata kelola laboratorium serta materi IPA terintegrasi dengan } \\
\text { potensi lingkungan sekitar. Metode yang dipakai dalam pencapaian tujuan }\end{array}$ \\
\hline
\end{tabular}




\section{Kata kunci}

Keterampilan, KIT praktikumIPAterintegrasi, scientific approach tersebut adalah penyelenggaraan inservice berupa pelatihan dan pendampingan. Pelatihan yang dilaksanakan adalah pelatihan mengembangkan keterampilan dan kreativitas guru IPA dalam produksi/merancang perangkat praktikum IPA terintegrasi berbasis lingkungan sekitar dan pelatihan merancang pembelajaran menggunakan pendekatan saintifik (scientific approach) yang memanfaatkan KIT IPA yang sudah diproduksi. Pendampingan juga dilakukan terkait dengan meningkatkan kemampuan guru dalam mengeksplorasi, mengelaborasi dan merefleksi materi ajar IPA terpadu. Luaran kegiatan ini berupa KIT alat praktikum terintegrasi berbasis lingkungan dilengkapi SOP tata laksana praktikum bermuatan lingkungan sekitar; Perangkat praktikum terintegrasi dalam pembelajaran IPA terpadu (RPP, LKS, panduan guru) sebagai penunjang pembelajaran scientific approach; SOP tata kelola laboratorium IPA terintegratif; Bahan ajar penyegaran materi IPA terpadu; Artikel ilmiah (publikasi nasional). Hasil kegiatan yang telah dicapai antara lain, meningkatnya pemahaman dan keterampilan guru-guru IPA di Kelompok guru IPA SMPN 1 Jerowaru terhadap materi IPA secara terintegrasi, meningkatnya pemahaman guru-guru tentang pembelajaran dengan pendekatan inkuiri, meningkatnya keterampilan guru-guru IPA merancang/membuat KIT IPA sederhana berbahan baku dari lingkungan sekitar sebagai penunjang pembelajaran IPA menggunakan pendekatan inkuari discovery (scientific approach), meningkatnya kemampuan guru-guru IPA untuk merancang perangkat pembelajaran dengan pendekatan inkuari discovery (scientific approach), terlatihnya keterampilan dan kemampuan guru-guru IPA di sekolah mitra dalam mengimplementasikan pembelajaran IPA dengan pendekatan inkuari discovery (scientific approach).

Sitasi: Syahidi, K., Zahara, L., \& Ariandani, N. Pendekatan Scientific Approach dalam Mengembangkan Alat Praktikum IPA Terintegrasi Lingkungan untuk Meningkatkan Keterampilan dan Kreativitas Guru IPA. Kappa Journal, Pendidikan Fisika, FMIPA, Universitas Hamzanwadi. 3 (2), 148-155

\section{PENDAHULUAN}

SMPN 1 Jerowaru merupakan salah satu sekolah yang berada di daerah terpencil yaitu terletak di jln.Pemongkong - Kaliantan, Desa Pemongkong, Kec. Jerowaru, Kab. Lombok Timur.Sekolah ini memiliki guru sebanyak 22 orang, jumlah rombel sebanyak 9 kelas dengan jumlah siswa saat ini sebanyak 270 siswa yang terdiri dari 133 siswa laki-laki dan 137 siswa perempuan. Kurikulum yang digunakan saat ini adalah K13. Dengan lokasi yang cukup jauh dari pusat kota kabupaten yang jaraknya sekitar $\pm 35 \mathrm{Km}$. Kondisi lingkungan sekitar masih alami, berupa daerah persawahan/perkebunan dan perumahan masyarakat desa setempat. Letak sekolah juga tidak jauh dari pesisir pantai yang merupakan daerah tujuan wisata diantaranya pantai Kaliantan jaraknya $\pm 3.3 \mathrm{~km}$, pantai Kura-Kura $\pm 5.19 \mathrm{~km}$, pantai Tangsi \pm $9.26 \mathrm{~km}$. Kondisi lingkungan sekolah tersebut sesungguhnya sangat potensial dimanfaatkan sebagai media pembelajaran. Di samping lingkungan alamnya, lingkungan sosial ekonomi daerah sekitarnya juga sangat potensial dijadikan objek pembelajaran berbasis lingkungan. Berbagai jenis mata pencaharian yang digeluti penduduk desa di sekitar sekolah, seperti: pertanian, peternak, nelayan, dan lain-lain sangat potensial dimanfaatkan sebagai media/objek pembelajaran terintegrasi.

Guru-guru mata pelajaran IPA Terpadu di SMPN 1 Jerowaru masih mengalami banyak kendala/hambatan dalam mengimplementasikan pembelajaran sesuai kurikulum 2013.Menurut kurikulum 2013, pembelajaran mestinya lebih menekankan pada dimensi pedagogik modern, yaitu menggunakan scientific approach.Pembelajaran yang relevan diterapkan adalah pembelajaran melalui eksperimen (praktikum).Pembelajaran yang diupayakan harusnya pembelajaran berbasis aktivitas (Kemendikbud. 2013).Dengan demikian, untuk pencapaian tujuan kurikulum 2013 (khususnya pada pembelajaran IPA) 
yang menekankan pendekatan ilmiah (scientific approach), keberadaan perangkat laboratorium menjadi sangat esensial.Namun, berdasarkan hasil obserbasi di lapangan, kondisi fasilitas sarana dan prasarana laboratorium IPA SMPN 1 Jerowaru ternyata masih jauh dari harapan. Fakta-fakta yang dijumpai di lapangan menunjukkan antara lain: (1) fasilitas, alat dan bahan praktikum yang ada jika dibandingkan dengan rasio jumlah peserta didik pemakai laboratorium masih sangat minim, (2) alokasi dana dari sekolah relatif sangat minim, droping alat dari kementerian pendidikan dan kebudayaan sering tidak sesuai kebutuhan, sementara tidak ada upaya kreatif dan inovatif oleh pengelola laboratorium untuk mengatasi kondisi tersebut, (3) laboratorium kurang difungsikan secara optimal sebagai tempat melaksanakan eksperimen, bahkan ruang laboratorium dialihfungsikan sebagai ruang kelas, (4) tidak adanya tenaga laboran, yang khusus bertugas secara rutin menyiapkan alat dan bahan yang dibutukan oleh guru IPA untuk kegiatan praktikum (Subamia, I.D.P, dkk. 2012).

Dari hasil wawancara dengan guru-guru IPA di SMPN 1 Jerowaru terungkap bahwa mereka juga mengalami kesulitan dalam mengimplementasikan pembelajaran IPA terpadu.Materi pembelajaran IPA terpadu (yang mencakup aspek fisika, biologi, kimia) menjadi salah satu kendala bagi mereka.Hal ini terkait dengan latar belakang pendidikan mereka.Latar belakang pendidikan mereka sesungguhnya adalah pendidikan biologi atau pendidikan fisika, sementara materi pelajaran IPA yang harus diajarkan mencakup aspek fisika, biologi, dan kimia.Guru-guru IPA di SMP N 1 Jerowaru menyatakan bahwa mereka sangat membutuhkan program pembekalan/pemantapan materi IPA terpadu.

Permasalahan yang dikemukakan di atas sampai sekarang belum memperoleh solusi yang tepat.Selain aspek sarana dan prasarana, guru-guru mitra menyadari bahwa mereka belum memiliki keterampilan yang memadai dalam mengelola pembelajaran menggunakan pendekatan ilmiah (scientific appoach). Guru kurang memperoleh inservice tentang pembelajaran menggunakan pendekatan ilmiah. Guru belum biasa dan terlatih memanfaatkan lingkungan sebagai laboratorium dalam memfasilitasi kegiatan praktikum siswa. Beberapa permasalahan yang dihadapi guru dalam mengelola kegiatan praktikum, seperti: (1) pemilihan fenomena atau kasus kontekstual yang relevan dengan konsep dan prinsip yang ditekankan dalam pembelajaran; (2) mengarahkan pengamatan siswa dalam praktikum. Guru yang kreatif yang memiliki keterampilan mengelola kegiatan praktikumsebenarnya potensial dalam mengembangkan alternatif pembelajaran menggunakan pendekatan ilmiah (scientific appoach) dengan memanfaatkan lingkungan yang ada sebagai media pembelajaran.

Guru mitra mengungkapkan bahwa mereka dari dulu sangat ingin memiliki keterampilan mengelola pembelajaran IPA berbasis lingkungan. Mereka ingin memiliki kemampuan dalam membuat media KIT praktikum IPA terintegrasi yang mudah diterapkan.Mereka juga mengemukakan bahwa pembekalan/pemantapan materi IPA terpadu masih sangat dibutuhkan. Guru-guru sangat berharap melalui kegiatan Program Kemitraan Masyarakat (PkM) ini keinginan mereka akan dapat diwujudkan.

Walaupun memiliki potensi lingkungan yang sangat beragam untuk media belajar namun guru-guru IPA enggan berkreasi/berinovasi untuk memanfaatkan lingkungan sebagai media belajar, apalagi memanfaatkan lingkungan sebagai sumber pembuatan KIT praktikum IPA.Padahal bahan-bahan lokal dan unsur kearifan lokal (baik alam maupun sosial) sangat potensial dikembangkan untuk membuat KIT praktikum IPA terintegrasi yang mudah dikerjakan.Lingkungan sekitar sekolah juga sangat potensial dimanfaatkan sebagai objek pembelajaran terintegrasi. 
Bertolak dari fenomena yang diuraikan di atas maka untuk mewujudkan peran strategis laboratorium dalam pembelajaran IPA sesuai kurikulum 2013, maka upaya untuk meningkatkan kompetensi tata kelola tata laksana laboratorium berorientasi lingkungan dan pengembangan perangkat praktikum terintegrasi dalam pembelajaran IPA terpadu di SMP serta pengembangan perangkat pembelajaran berbasis lingkungan sekitar sangat diperlukan Berdasarkan paparan di atas, sangat perlu dilakukan PkM bagi guru-guru IPA di sekolah mitra (SMPN 1 Jerowaru).

\section{METODE}

Metode yang diterapkan dalam pengabdian ini adalah aplikasi teknologi pembelajaran dan teknologi pengadaan media pembelajaran alternatif dengan mengungkap permasalahan yang muncul dikalangan para guru, kemudian dilakukan diskusi pengusul bersama mitra untuk merumuskan akar masalah prioritas yang disepakati, serta menentukan solusi yang tepat.Bahwa tidak efektifnya serta rendahnya penerapan pendekatan ilmiah yang diterapkan oleh guru IPA di SMPN 1 Jerowaru berpangkal pada tidak tersedianya media pendukung yang memadai.Sementara, guru-guru tidak memiliki keterampilan yang memadai untuk pengadaan media alternative yang mudah diterapkan. Di sisi lain, kondisi lingkungan sekitar sekolah SMPN 1 Jerowaru sangat potensial diberdayakan/dimanfaatkan sebagai media pembelajaran dengan pendekatan ilmiah. Memperhatikan alasan tersebut, sebagai upaya untuk meningkatkan mutu pembelajaran IPA pengusul dan mitra menyepakati dan menjustifikasi solusi yang paling mungkin dilakukan adalah pelatihan dan pendampingan merancang media pembelajaran berorientasi lingkungan .Dalam pelaksanaannya metode pendekatan yang ditawarkan adalah partisipatori. Dalam artian tim pengusul dan mitra secara proaktif terlibat dalam setiap kegiatan.

Potensi lingkungan yang sangat beragam yang ada di sekitar sekolah sangat potensial dimanfaatkan sebagai sumber media belajar IPA.Melalui sentuhan teknologi sederhana dan sedikit kreativitas dapat diproduksi KIT-KIT percobaan/praktikum IPA terintegrasi berbasis lingkungan sekitar.Dengan demikian kendala keterbatasan alat-alat dan bahan praktikum dalam pembelajaran IPA dapat teratasi.Solusi untuk permasalahan pokok yang kedua yaitu terkait dengan mengelola pembelajaran IPA terpadu menggunakan pendekatan saintifikdilakukan dengan pembekalan metode pembelajaran dan penyegaran materi IPA terpadu. Potensi sosial ekonomi (terdapatnya berbagai industri kerajinan rumah tangga yang ada di wilayah desa sekitar sekolah seperti : pertanian, peternakan, dll) dapat dimanfaatkan sebagai objek pembelajaran IPA terintegrasi berbasis lingkungan.

Berdasarkan kajian empiris yang telah dipaparkan di atas, maka pendekatan solusi yang digunakan untuk memecahkan dua permasalahan pokok yang dihadapi sekolah mitra adalah penyelenggaraan inservice berupa pelatihan dan pendampingan. Dua target pelatihan adalah pelatihan mengembangkan keterampilan dan kreativitas guru IPA dalam produksi/merancang model KIT praktikum IPA terintegrasi berbasis lingkungan dan pelatihan merancang pembelajaran menggunakan pendekatan saintifikyangmemanfaatkan KIT IPA yang sudah diproduksi. Pendampingan dilakukan terkait dengan meningkatkan keterampilan guru dalam mengimplementasikan rancangan pembelajaran yang dibuat sekaligus penyempurnaan rancangan pembelajaran.Pendampingan juga dilakukan terkait dengan meningkatkan kemampuan guru dalam mengeksplorasi, mengelaborasi dan merefleksi materi ajar IPA terpadu (mencakup aspek fisika, biologi, dan kimia) dengan pendekatan ilmiah. 


\section{HASIL DAN PEMBAHASAN}

Berdasarkan hasil penelitian dan pelatihan yang sudah dilaksanakan ada beberapa hasil yang sudah didapatkan berdasarkan langkah-langkah sebagai berikut:

\section{Hasil Kegiatan Pra Kegiatan Utama}

Sebelum pelaksanaan kegiatan utama, dilakukan kegiatan pendahuluan berupa penyegaran materi IPA terpadu (SMP kelas VII), pembekalan/pendalaman model pembelajaran dengan pendekatan inkuiri dan pelatihan teknik-teknik merancang alat-alat peraga. Kegiatan ini bertujuan meng-upgrade dan menyegarkan pemahaman guru tentang materi IPA terpadu terutama materi pelajaran yang bukan bidangnya. Kelompok guru IPA yang basic keilmuannya bidang biologi diajak mendalami bidang kimia dan fisika. Demikian pula kelompok guru IPA dengan basic keilmuannya bidang fisika disegarkan dengan materi bidang biologi dan kimia.

Setelah mengikuti kegiatan tersebut, guru-guru IPA menyatakan bahwa pemahaman mereka tentang materi IPA terpadu menjadi lebih baik. Mereka merasa lebih percaya diri untuk membelajarkan mata pelajaran IPA terpadu di kelas. Demikian pula pemahaman mereka mengenai model pembelajaran dengan pendekatan inkuiri menjadi dipahami lebih jelas.

\section{Kegiatan Utama Pelatihan 1}

Pelatihan 1 difokuskan untuk mensosialisasi bentuk RPP, LKS, model KIT IPA dan Panduan guru tentang pembelajaran IPA terpadu menggunakan pendekatan inkuiri. Materi pelatihan mencakup penjelasan tentang contoh-contoh perangkat pembelajaran di atas discovery dan alur kerja dalam mewujudkan semua perangkat tersebut, yaitu dari: (1) analisis konsep kunci berdasarkan kompetensi dasar (KD), (2) penyusunan indikator pembelajaran berdasarkan konsep/prinsip kunci, (3) penetapan konteks/fakta laboratorium yang digunakan dalam mendukung pembelajaran pada konsep/prinsip kunci, penyusunan RPP, (4) penyusunan petujuk praktikum berupa lembar kerja siswa (LKS) dan SOP berlaboratorium, (5) pembuatan KIT IPA, dan penyusunan Panduan bagi guru.

\section{Pelatihan 2}

Pada pelatihan 2 ini dilakukan pendampingan pembuatan perangkat pembelajaran menggunakan pendekatan inkuiri discovery terkait topik yang diidentifikasi. Kegiatan mencakup penyusunan RPP dengan pendekatan inkuiri discovery, pembuatan prosedur kerja praktikum berupa lembar kerja siswa (LKS), dan penyusunan panduan bagi guru. Pada pelatihan ini dilakukan pembahasan tentang draft RPP yang dibuat masing-masing guru mitra. Pada pelatihan 2 dilatihkan cara mengembangkan LKS mengacu pada RPP dan konteks/fakta laboratorium yang telah diidentifikasi. Diskusi secara intensif tentang fenomena dan bagaimana mengembangkan pertanyaan untuk mengarahkan cara berpikir siswa berlangsung antara guru mitra-guru mitra, dan guru mitra-tim pelaksana.

Pada pelatihan ini, didampingi tim pelaksana guru mitra menetapkan beberapa kompetensi dasar (KD) untuk dianalisis konsep/prinsip kuncinya sekaligus mengidentifikasi konteks/fakta laboratorium terintegrasi yang sesuai dengan pembelajaran pada konsep/prinsip kunci tersebut. Pelatihan ini ditindaklanjuti dengan penyusunan RPP untuk satu tema yang mengintegrasikan beberapa kompetensi dasar IPA SMP kelas VII semester 1 yang menuntut kegiatan inkuiri discovery (praktikum). Hasil kegiatan berupa RPP, LKS dan panduan bagi guru (terlampir). Berikut adalah contoh petunjuk praktikum (LKS) yang dikembangkan (dikerjakan) oleh guru mitra.

\section{Pelatihan III}

Pelatihan 3 berupa kegiatan pendampingan pembuatan rancangan KIT IPA serta alat/bahan kelengkapan keperluan praktikum sesuai LKS yang telah disusun. KIT IPA ini dikemas dalam kemasan kotak yang terbuat dari kayu dan triplek. Dalam kotak KIT berisi alat dan sekaligus bahan yang dibutuhkan untuk kegiatan praktikum sesuai petunjuk 
praktikum (LKS). Alat dan bahan yang dipakai sebagian besar dengan pemanfaatan barangbarang bekas dan bahan-bahan yang mudah didapat dari lingkungan sekitar. Misalnya, untuk mengganti alat-alat gelas dipakai gelas bekas air minuman mineral, pembakar spiritus dibuat dari botol bekas minuman suplemen, untuk alat ukur dimanfaatkan spite bekas injector tinta printer reftil, pengganti tabung reaksi dimanfaatkan botol bening kecil bekas tempat parfum.

Demikian pula bahan-bahan yang dirujuk dalam petunjuk praktikum (LKS), memanfaatkan bahan-bahan yang mudah diperoleh dari lingkungan sekitar. Misalnya, untuk bahan indikator memanfaatkan bahan-bahan alam seperti kunir, bunga kol, kembang ungu, dll. Untuk pengenalan larutan asam, basa dan garam menggunakan asam alami (cuka, ekstrak buah jeruk), larutan basa (kapur tohor, batu kapur, abu, dll). Garam, menggunakan garam dapur, air laut, dll.

\section{Pelatihan IV}

Uji coba kelayakan penggunaan KIT IPA dilakukan untuk menguji apakah rancangan KIT yang dibuat sudah bisa diterapkan sebelum dicobakan di kelas.

Dari hasil penilaian, model KIT IPA berorientasi lingkungan yang dikembangkan sudah memenuhi kriteria relevan dan layak. Dari komentar penilai juga diketahui bahwa perangkat praktikum yang dikembangkan memiliki kelebihan dengan perangkat praktikum standar, antara lain: 1) perangkat praktikum ini disesuaikan dengan kurikulum 2013 yang menuntut pembelajaran IPA SMP dilakukan dengan pendekatan ilmiah (scientific approach); 2) konten materi praktikumnya terintegrasi, diupayakan sesuai dengan konten IPA terpadu; 3) perangkat praktikum ini merujuk bahan/alat yang dekat dan mudah diperoleh dari lingkungan sekitar; 4) memberikan kemudahan bagi siswa untuk melakukan kegiatan, karena petunjuk praktikum (LKS) diadaptasi dari petunjuk percobaan (kegiatan) yang sudah tercantum pada buku siswa; 5) memberikan kemudahan bagi guru dalam melaksanakan proses pembelajaran dengan eksperimen karena perangkat penunjang praktikum telah tersusun dengan rapi dalam satu kotak kemasan (KIT IPA) dan dilengkapi instruksi kerja alat. Sementara itu, kekurangan KIT IPA ini adalah (1) belum mencakup materi IPA terpadu, (2) petunjuk perlu dibuat lebih terstruktur agar memberi tuntunan secara mudah dan cepat kepada siswa, dan (3) perlu dilengkapi soal-soal pendalaman untuk mengeksplorasi pemahaman siswa terhadap konsep-konsep yang dibelajarkan.

Berdasarkan hasil penilaian tim ahli dan masukan dari praktisi dilakukan revisi dan penyempurnaan perangkat. Pada kegiatan ini tim pelaksana mendampingi guru mitra merevisi dan melakukan penyempurnaan perangkat pembelajaran (RPP, LKS, KIT IPA).

\section{Pelatihan V}

Pada kegiatan ini dilakukan penerapan pembelajaran inkuiri discovery memanfaatkan perangkat yang telah dikerjakan oleh guru mitra. Salah seorang guru mitra tampil sebagai guru model, sementara guru-guru yang lain memantau bersama tim pelaksana.

Hasil penilaian oleh siswa terhadap pemanfaatan produk pada pembelajaran dengan pendekatan inkuiri termasuk kategori baik. Respon siswa pada pembelajaran yang memanfaatkan perangkat praktikum berorientasi lingkungan lebih baik dan lebih menyenangkan daripada respon siswa pada pembelajaran konvensional (tanpa menggunakan KIT IPA). Siswa menunjukkan respon positif (skor rata-rata 89,6\%). Dari hasil pengamatan terhadap aktivitas siswa, pada pembelajaran memanfaatkan perangkat praktikum berorientasi lingkungan siswa lebih aktif dibandingkan pada pembelajaran tanpa perangkat praktikum. Aktivitas siswa terhadap pemanfaatan perangkat praktikum berorientasi lingkungan dalam pembelajaran IPA termasuk sangat positif $(96,8 \%)$. Hal tersebut menunjukkan bahwa perangkat praktikum yang dikerjakan mampu mendukung proses pembelajaran IPA menjadi lebih menarik. 


\section{KESIMPULAN}

Kesimpulan sementara yang bisa diambil adalah bahwa kegiatan ini berlangsung dengan baik sesuai dengan yang direncanakan. Guru-guru dari sekolah mitra antusias dan berpartisifasi aktif dalam melaksanakan kegiatan. Sebagian besar guru mitra masih membutuhkan penyegaran materi IPA terpadu, keterampilan dalam mengembangkan pembelajaran IPA terpadu menggunakan pendekatan inkuiri discovery beserta penyusunan perangkat pendukung pembelajarannya juga belum optimal. Keterampilan guru mitra dalam membuat KIT IPA terintegrasi juga masih perlu mandapat pendampingan lebih intensif. Perlu ada pendampingan lebih lanjut bagi guru-guru dalam mengimplementasikan pembelajaran IPA terpadu dengan inkuiri discovery.

Guru memberi respon positif terhadap perangkat praktikum IPA berorientasi lingkungan, baik dari kemudahan mempersiapkan maupun dari kemudahan mengimplementasikannya (skor rata-rata 3,4). Dari hasil tersebut, dapat disimpulkan bahwa model perangkat praktikum berorientasi lingkungan yang dikembangkan sudah memenuhi kriteria relevan dan mudah digunakan. Respon siswa terhadap pemanfaatan perangkat praktikum berorientasi lingkungan dalam pembelajaran IPA diperoleh hasil, yaitu: jumlah siswa yang memberikan respon positif sebesar $83,3 \%$ dan memberi respon sangat positif sebesar $4,7 \%$. Jumlah siswa yang memberi respon posistif dan sangat positif adalah $88 \%$. Hal tersebut menunjukkan bahwa perangkat praktikum mampu mendukung proses pembelajaran IPA menjadi lebih menarik. Hasil wawancara dengan guru menunjukkan bahwa guru memberi kesan positif terhadap perangkat praktikum berorientasi lingkungan, baik dari mudahnya mempersiapkan maupun dari mudahnya mengaplikasikannya.

\section{SARAN}

Berdasarkan hasil yang kami peroleh bahwa pembelajaran dengan scientific approach perlu berbasis lingkungan sekitar perlu diterapkan di sekolah-sekolah yang lain karena mampu meningkatkan pemahaman dan keterampilan guru-guru IPA di Kelompok guru IPA SMPN 1 Jerowaru.

\section{UCAPAN TERIMA KASIH}

Penulis mengucapkan terimakasih kepada :

1. DRPM Ristekdikti yang telah memfasilitasi dalam pelaksanaan PkM ini.

2. Rekan-rekan dosen di Universitas Hamzanwadi selong atas bantuan dan motivasi dalam menyelesaikan penelitian ini

3. Kepala SMPN 1 Jerowaru dan Ketua Kelompok IPA SMP Kec. Jerowaru atas kerjasamanya dalam memberikan izin penelitian di wilayahnya.

4. Semua pihak yang sudah membantu dalam menyelesaikan penelitian ini

\section{DAFTAR PUSTAKA}

Kemendikbud. 2013. Kurikulum 2013, Kompetensi Dasar Sekolah Menengah Pertama (SMP)/ Madrasah Tsanawiyah (MTs).

Novianti, N.R. 2011. Kontribusi Pengelolaan Laboratorium dan Motivasi Belajar Siswa Tehadap Efektifitas Proses Pembelajaran (Penelitian pada SMP Negeri dan Swasta di Kabupaten Kuningan Provinsi JawaBarat). Jurnal.Upi.Edu/File/15. Edisi Khusus No. 1, Agustus 2011. ISSN 1412-565X

Santoso, T. T. 2010. Pemanfaatan Media Alam Sekitar untuk Meningkatkan Hasil Belajar Siswa dalam Pembelajaran Tematik Tema Lingkungan.Jurnal Pendidikan Kimia Tentang Media Lingkungan Sekitar. 
Subamia, I.D.P, dkk. 2012. Pelatihan Keterampilan Dasar Laboratorium (Basic Skill Laboratory) Bagi Staf Laboraorium IPA SMP Se-Kabupaten Buleleng. Jurnal pengabdian Kepada Masyarakat Widya Laksana Undiksha: Edisi Juli 2012. ISSN: 1410-4269.

Sukarta, dkk. 2012. Pelatihan Pembelajaran Inovatif Bagi Guru-guru di SMP Negeri 2 Kubu. Jurnal pengabdian Kepada Masyarakat Widya Laksana Undiksha: Edisi Juli 2012. ISSN: $1410-4269$. 